\title{
Childbirth in aristocratic households of Heian Japan
}

\author{
Anna Andreeva (*) \\ $\left({ }^{*}\right)$ Cluster of Excellence «Asia and Europe in a Global Context». Karl Jaspers Centre for \\ Advanced Transcultural Studies, Universität Heidelberg \\ andreeva@asia-europe.uni-heidelberg.de
}

Dynamis

[0211-9536] 2014; 34 (2): 357-376

http://dx.doi.org/10.4321/S0211-95362014000200005
Fecha de recepción: 21 de enero de 2013

Fecha de aceptación: 7 de febrero de 2014

SUMMARY: 1.-Delivery and danger. 2.-The ritual economy of childbirth. 3.-Sights, smells, colours, and sounds during the labour. 4.-Midwives and physicians. 5.-Co-existing paradigms of knowledge.

ABSTRACT: This paper focuses on childbirth in Japan's aristocratic households during the Heian period (794-1185). Drawing on various sources, including court diaries, visual sources, literary records, and Japan's first medical collection, with its assortment of gynaecological and obstetric prescriptions, as well as Buddhist and other ritual texts, this short excursion into the cultural history of childbirth offers an insight into how childbirth was experienced and managed in Heian Japan. In particular, it addresses the variety of ideas, knowledge systems and professionals involved in framing and supporting the process of childbirth in elite households. In so doing, it casts light on the complex background of early Japanese medicine and healthcare for women.

PALABRAS CLAVE: Parto, rituales de partos, parteras, médicos, periodo Heian, Japón.

KEY WORDS: Childbirth, childbirth rituals, midwives, physicians, Heian Japan.

\section{Delivery and danger $(*)$}

During the Heian period (794-1185), childbirth was associated with a serious risk of death, propensity for illness, pollution and danger. It was

$\left(^{*}\right)$ This paper is a part of a larger project on the cultural history of childbirth in pre-modern Japan, which was partially conducted under the auspices of project C11 «Religion and Medicine in Pre-Modern East Asia», sponsored by the German Research Council (DFG) and Cluster of Excellence "Asia and Europe in a Global Context», during 2010-12. A subsequent version of 
an event charged with uncertainty, where time and space inhabited by the living was believed to momentarily overlap with the realms of the dead, unseen malevolent spirits, and the Buddhist, Shinto and other deities. The probability of mortality for both the woman in labour and the infant was undoubtedly quite high. Thus, it was an event at which the presence of medical and ritual assistance and authority was required.

Some of the best-known early medieval hand-painted scrolls such as the Kitano Tenjin emaki 北野天神絵巻 («The Picture Scroll of the Kitano Shrine Deity») and Gaki zôshi 餓鬼草子 («The Scroll of Hungry Ghosts») depicted the biological event of childbirth as embedded in the religious worldview of Shinto-Buddhist combinatory worship. These scenes, most likely illustrating the childbirths that took place in aristocratic households, appear to be framed by symbolic actions of a variety of specialists and different paradigms of knowledge, both medical and religious.

For example, «The Scroll of Hungry Ghosts», itself a didactic device produced in the late 12th-to early 13 th century, is one of the primary visual sources that illustrated the impermanence of human existence and explained the nature of transmigration; both notions were important in Buddhist ideology, a dominant framework permeating all sides of life in Japan's pre-modern society. In compliance with the contemporary ideas and practices, this scroll depicted the dangerous nature of childbirth in the following scene ${ }^{1}$.

At the centre of a rectangular room separated from the rest of the house by blinds and sliding doors is a parturient woman in white-coloured robes, squatting on a mat in a forward-slumping motion. Exhausted by her labour, she is looking down at a small, dark-haired baby whom she has just delivered. The baby is lying on its back in what appears to be a pool of blood and afterbirth.

The parturient woman, most likely a noble lady from an elite household, is surrounded by a protective circle of her female attendants. One supports her from behind, while another offers her own shoulder, extending arms

this paper was presented at the Pre-Modern Japan Seminar, University of Southern California, Los Angeles, in March 2013 and at the International Research Center for Japanese Studies (Nichibunken) in Kyoto, in June 2013.

1. Gaki zôshi («The Scroll of Hungry Ghosts»), the childbirth scene. Late 12th-early 13th century. Tokyo National Museum, e-Kokuhô collection, image no. C0016935, item A-10476. Available from: http://webarchives.tnm.jp/imgsearch/show/C0016935 [cited Feb 22, 2013] 
to receive the newborn. The third attendant, seen only from her back, is sitting in the right lower corner, smashing clay dishes in a bid to ward off the unseen evil spirits' presence. She faces an old woman in a tea-coloured robe and a white hood over her head, presumably a midwife, who seems to exude a delighted laughter. Two more women are sitting anxiously on the opposite side; one, wearing a brown cloak, is in conversation with a male courtier $^{2}$, who has a long thin object in his hand (possibly, a bow), entering the birth room from the outer chambers of the house through the sliding door on the left. Pointing toward the baby, a female attendant is conveying the news of the child being born. Several barrels of white rice are standing on the side of the room, with more fragments of broken dishes lying about, attesting to the length of the labour.

In the midst of this otherwise auspicious scene is the reminder of what was supposed to remain unseen to the protagonists of this scroll: an emaciated hungry ghost, with its red hair standing on end, a distended stomach and a large tongue protruding from its open mouth, extending its bone-thin fingers and arms towards the infant and the pool of blood into which the baby has just descended. According to the Buddhist cosmology, such hungry ghosts inhabited one of the lower realms of beings. Doomed by their bad karma to scavenge for any scraps of food, human remains or even excrement, these ghosts were believed to wander endlessly in the human realm and gather at the moments of near-fatal or border-line liminal existence, expecting to prey on the just deceased or the newly born. It was believed that childbirth with its inevitable flow of parturition blood and afterbirth, or the sites of battle with many casualties and scattered body parts, would attract these lowly and fearsome malevolent spirits.

Thus, at the centre of this portrayal is the implied idea that childbirth was a risky affair, which was likely to result in mother or infant's death, leaving a parturient woman vulnerable to the attack of the hungry ghosts preying on the parturition blood and afterbirth. Largely didactic in nature, the childbirth scene from the «Scroll of Hungry Ghosts» reflects the fragility and instability of human life as a particular plight of women and asserts the

2. Male courtiers, most likely relatives or members of court retinue, were supposed to ward off malignant spirits with a bow and arrow. Matsumoto Ikuyo, (Yokohama City University), «Parturition Rituals of Medieval Japanese Empresses: Protection of the Female Body in Esoteric Buddhism», paper presented at the workshop «Imagining the Feminine» held at the Karl Jaspers Centre, University of Heidelberg, in November 2010. 
notion that childbirth was a critical event in women's and newborn babies' lives, one fraught with risk and danger. High infant and maternal mortality were constant sources of anxiety in pre-modern Japan, and miscarriages, premature births and stillborn babies were common ${ }^{3}$. Parturient women no doubt feared their impending labour, but at the same time, they had to accept the inevitable course of events.

However, it was also believed that such dangers could be successfully averted. The childbirth scene in the «Scroll of Hungry Ghosts» further attests to such possibilities. Separated from the birth room by a wall and semi-transparent blinds is another section of the house, which represents the semi-outer space of the birth chamber, or in other words, the «outer frame» of the childbirth process.

Another midwife or a court lady in dark coloured robes is seen in the doorway between the birth chamber and its neighbouring room, as if mediating the tense space between the birth chamber with the woman in labour, her attendants, midwives, the hungry ghost and the baby, and the outer room. There, on a tatami mat, is seated a Buddhist monk with a shaven head, wearing cleric's robes, with a rosary in his hands. Engrossed in conversation with the attendant woman who points towards the scene of childbirth, the monk might be receiving further requests for chanting the sutras or performing further rituals. But that is not all.

Directly opposite him is a female medium, miko, who serves as a ritual «receptacle» for the ghosts and spirits assumed to be present during the labour and childbirth. She acts as a counterpart to, or in tandem with the Buddhist cleric who is tasked with overseeing the process of her spirit possession. We can only see the miko's flowing red trousers and abundant black hair scattered on her back. Her outer garments are pushed back, next to a flat box, in which she may keep her few ritual implements. She may have performed additional prayers; more importantly, she could still be possessed by the malignant spirit depicted in the birth room. Acting as a medium, the miko would embody the visitors from the realm of the unseen and voice their grievances, providing clues for further actions by the Buddhist cleric. Some textual examples will follow shortly.

3. Useful observations on demographic history of medieval Japan can be found in Farris, William Wayne. Japan's Medieval Population: Famine, Fertility and Warfare in a Transformative Age. Honolulu: University of Hawai'i Press; 2006, especially, p. 8-10 and 88-90. 


\section{The ritual economy of childbirth}

While the «Scroll of Hungry Ghosts», dated from the late 12th or 13th century, leaves it unclear what kind of services exactly these two religious practitioners provided, an examination of earlier historical and literary sources reveals much more in detail.

The hungry ghosts and harmful spirits gathering in birth chambers during the critical times presented a sizeable threat to a woman in labour; it was considered best to identify them and let the ritual specialists get rid of them. Such practices were well known and often described in the Heianperiod and later sources. For example, the Tale of Genji, Japan's renowned early eleventh-century novel, describes the case of the protagonist's heavily pregnant wife Aoi, who is shortly to give birth at an aristocratic household in the Heian capital. She suffers from being possessed by a spirit of a jealous woman, who was in fact Genji's previous lover.

«(...) At Sanjô, Genji's wife seemed to be in the grip of a malign spirit... He had prayers read in his rooms. Several baleful spirits were transferred to the medium and identified themselves, but there was one which quite refused to move. Though it did not cause great pain, it refused to leave her for so much as an instant. There was something very sinister about a spirit that eluded the powers of the most skilled exorcists... The confusion and worry continued. The lady would sometimes weep in loud wailing sobs, and sometimes be tormented by nausea and shortness of breath. (...) The malign spirit was more insistent, and Aoi was in great distress» 4 .

As seen from this abstract, the physical symptoms experienced by the labouring woman, both expected and highly abnormal, were often attributed to the actions of malevolent spirits; their presence and threat to the woman in labour and the newborn baby was undoubted.

Contemporaneous historical records and personal diaries of courtiers, such as Midô kanpakuki 御堂関白記, the diary of the Regent Fujiwara no Michinaga (966-1027) ${ }^{5}$, and Murasaki Shikibu Nikki 紫式部日記, a personal

4. Translation adapted from Seidensticker, Edward, tr. The Tale of Genji, by Murasaki Shikibu. New York: Alfred Knopf; [1976] 1992, p. 174-75, and 176. On jealousy and spirit possession in the Tale of Genji, see Bargen, Doris. A woman's weapon: spirit possession in the Tale of Genji. Honolulu: University of Hawai'i Press; 1997.

5. Fujiwara no Michinaga, the most powerful man of his day, kept his diary between 998 and 1027, recording most of his personal and public affairs. This diary remains one of the more reliable historical records produced during the Heian period. 
record by the author of the aforementioned Tale of Genji, Murasaki no Shikibu (c. 973 - c. 1014 $)^{6}$, provide more details on the process of preparation and the birthing itself. Both sources meticulously describe the events before, during and after the labour of Princess Shôshi (or Akiko, 988-1074), the eldest daughter of Michinaga and the imperial consort of Emperor Ichijô (980-1011). This was Shôshi's first pregnancy; as per custom, she was moved from the imperial palace to her father's mansion for her confinement in the fifth year of the Kankô era (1008.07.16).

The labour was supposed to take place in the northernmost quarter of the mansion; according to the Yin-Yang theories and directional taboos, court diviners could calculate the most auspicious location for setting the birth chamber and positions during the labour ${ }^{7}$. For Shôshi's father, the prime minister and regent Fujiwara no Michinaga, the newborn baby was an extremely important grandchild - if it were a boy and thus the son of a reigning emperor, he would have a great potential for also becoming an emperor one day, thus allowing his grandfather an unprecedented access to power $^{8}$. In his diary, Michinaga recorded that Shôshi's labour had started in the middle of the night on the tenth day of the ninth month, necessitating all the preparations immediately ${ }^{9}$.

6. A court lady and renowned poet of her day, Murasaki no Shikibu, originally from the Fujiwara family, served as a lady-in-waiting to Princess Shôshi, the consort of emperor Ichijô and Michinaga's daughter. Her diary written around 1010 recorded the events of Shôshi's labour and the birth of imperial prince, which took place at Michinaga's house in 1008.

7. The practice of calculating such positions and, based on that, producing the birth charts (chantu) was well known in Sui (581-618AD) and Tang (618-907AD) China. The early Japanese medical collections also contained comparable prescriptions. Jen-der Lee. Childbirth in Early Imperial China. Nan Nü 2005; 7 (2): 216-286, especially, p. 228-230. See also the discussion of Shôshi's labour in Tonomura, Hitomi. Birth-giving and avoidance taboo: Women's body versus the historiography of ubuya. Japan Review, 2007; 19: 3-45 (esp. p. 16-19).

8. Michinaga had six children by his wife Rinshi: two sons and four daughters. As we shall see further, it was really the daughters who were responsible for his rise to power. Hurst, G. Cameron, III. Kugyô and Zuryô: Center and Periphery in the era of Fujiwara no Michinaga. In: Adolphson, Mikael; Kamens, Edward; Matsumoto, Stacie, eds. Heian Japan: Centers and Peripheries. Honolulu: University of Hawai'i Press. 2007, p. 66-101, particularly, p. 70-71.

9. Kuramoto Kazuhiro 倉本一宏, annotated modern Japanese translation. Fujiwara no Michinaga: Midô kanpakuki. (Fujiwara no Michinaga's Diary of the Lord of the Great Hall). Modern Japanese annotated edition, 3 vols. Kôdansha gakujutsu bunko. Tokyo: Kôdansha; 2009. Vol. 1, p. 364-365. 
Firstly, the room where the labour and childbirth were to take place had to be furnished and suitably equipped. Murasaki Shikibu who was then Princess Shôshi's closest lady-in-waiting, here recalled:

«As dawn approached on the morning of the tenth, they changed all the furnishings and Her Majesty [Shôshi] moved to a white-curtained dais. His Excellency [Fujiwara no Michinaga] was in charge, and his sons, with other courtiers (...) were milling about hanging up curtains and bringing in mats and cushions. Confusion reigned supreme» ${ }^{10}$.

Secondly, in preparation to the process of labour with its unpredictable outcome prone to meddling by hungry ghosts and unseen malevolent spirits, and the long-awaited moment of childbirth, the space, namely the birth room with the white-curtained dais on which the birth was to take place, had to be ritually secured, by all possible means. Here we find that a variety of ritual specialists were invited into the elite aristocratic household (as those could afford such costs); among them were famous Buddhist monks, namely, high-ranking clerics and princely abbots from the imperially designated temples, mountain religion ascetics experienced in exorcism, Yin-Yang diviners and astrologers, and female miko mediums. All were to pray for the benefit and safe delivery of the child and the princess in labour.

«Evil influences were warded off with the ceaseless chanting of loud spells. In addition to the priests who had been at the mansion for the last few months, every temple in the land had been requested to send anyone worthy of the name exorcist, and as they crowded in I could just imagine all the Buddhas in the universe flying down in response. Those known for their divining skills [Yin-Yang diviners] had also been ordered to attend; surely not a spirit in Japan could have failed to prick up their ears. The noise of messengers leaving to request the reading of sutras carried on throughout the night (...) The women acting as mediums sat in isolation to the west of the dais, each surrounded by a wall of screens. An exorcist assigned to each sat in front of the curtains that were placed at the entrance to these small enclosures, praying loudly» ${ }^{11}$.

10. Bowring, Richard John. Murasaki Shikibu, her diary and poetic memoirs: a translation and study. New Jersey: Princeton University Press; 1982, p. 51.

11. Bowring, n. 10; 1982, p. 51. 
Surprisingly, these records say little about the role of physicians and midwives. Perhaps, the Heian-period aristocracy was indebted to the power and efficacy of ritual much more than to the physician's knowledge? It was rather the Buddhist clerics who were invited in numbers to conduct the prayers and perform rituals, such as chanting the scriptures, usually the Lotus Sutra ${ }^{12}$, and incantations dedicated to the fierce-looking esoteric deity Fudô myôô: (Sk. Akala), the «Immovable Wisdom King», in order for the royal childbirth to proceed smoothly.

One of the five guardian deities worshipped as a set ${ }^{13}$ at court and leading esoteric Buddhist temples for the protection of state, Fudô myôô was usually depicted on hanging scrolls or carved as a statue, as a bluebodied male figure with fangs and fierce, gnarling expression, holding a long vajra-sword in his right hand and a rope with a hook in his left, with a blazing fire halo against his back. This deity was thought to possess the powers to cut off the evil influences and pull the stranded souls out of the depths of hell ${ }^{14}$.

«To the south, the bishops and archbishops of greatest importance sat in rows; it was quite terrifying to hear them, their voices hoarse with such a praying and wailing as to call up the very manifestation of Fudô» ${ }^{15}$.

12. The Sanskrit title of this scripture is Saddharma Pundarika Sûtra, Miaofa lianhua jing 妙法 蓮華経 in Chinese, and Jp. Myôhô rengekyô, or in short, Hokkekyô, in Japanese. One of the most popular and influential Buddhist scriptures, well-known in East and Southeast Asia, it consists of the discourse thought to have been delivered by Buddha toward the end of his life. Known in Chinese translation at least since the late third century, it became one of the major scriptures in the Tiantai school in China, as well as Tendai (and later, Nichiren) schools in Heian Japan.

13. «The Five Great Wisdom Kings» (Jp. Godai myôô 五大明王) were worshipped as a set for the protection of the state, both at court and in leading Tendai and Shingon Buddhist temples. Later records, such as the late Kamakura period collections Osan oinori no mokuroku 御産 御祈目録 (A List of Prayers for the August Childbirths; Zoku Gunsho Ruijû, vol. 33 ge) and Osan buruiki 御産部類記 (Assorted Accounts of the August Childbirths; Zoku Gunsho Ruijû, vol. $33 \mathrm{ge}$ ) documenting the births given by imperial consorts between 1120 and 1338s, mention that protective rituals invoking this set of deities were routinely performed during royal childbirths.

14. The aforementioned Osan buruiki (Assorted Accounts of the August Childbirths) also mentions other deities, such as Ususama myôjin, as well as astral magic and divination performed as a part of the royal childbirth ritual programme. For the sake of space, these records, although vital to my larger project, will not be discussed at length here.

15. Bowring, n. 10; 1982, p. 51. 
That this deity, most prominently invoked in ritual services for peace in the realm, was appealed to during royal childbirths, attests to the fact that the birth-giving body of the imperial consort was envisioned as a symbolic site vital for the protection of state and the nation. The important task of ensuring the ritual safety of childbirth and the well-being of the imperial consort necessitated a certain formal ritual protocol which required the presence of high-ranking Buddhist clerics and their official services. In return, they were amply rewarded with appropriate stipends, gifts and clothes while the household was preparing for the urgent necessities such as providing the wet nurse to the newborn baby, cutting the umbilical cord and arranging the first bath ${ }^{16}$.

\section{Sights, smells, colours, and sounds during the labour}

As seen from the aforementioned literary and historical sources, labour and childbirth would normally have to take place in a room or an antenatal chamber ${ }^{17}$ shielded from the public and equipped with specially arranged mats, cushions, covers, white folding screens and blinds. The parturient woman and her attendants would often be dressed in white garments. The labour and delivery were conducted either in a squatting position, on one's knees and supported under arms by a female attendant, or later, with support of a rope hanging from a ceiling.

In elite aristocratic households, however, this space for labour and childbirth may not have provided the parturient woman with a calm, serene atmosphere. Instead, this could be a space filled with commotion, constant

16. Fujiwara no Michinaga noted in his diary that the Buddhist monks and Yin-Yang diviners were given stipends, although there was a difference in amount given to each kind of specialist. Midô kanpakuki, entry of Kankô 5 (1008. 09.10-11). Kuramoto, n. 9; 2009, vol. 1, p. 364. Also, Jen-der Lee. Wet Nurses in Early Imperial China. Nan Nü 2000; 2 (1): 1-39.

17. In the case of Princess Shôshi such space was respectfully addressed to as osansho 御産所, literally «the place of august birth» (Midô kanpakuki, Kuramoto, n. 9; 2009, vol. 1: 364-365). Another well-known term, «birth room» or «parturition hut» (ubuya 産屋) may imply social class differences. Farris notes the use of the latter in the medieval sources. Farris, n. 4; 2006, p. 89. On «birth rooms» and «parturition huts» in pre-modern China and Japan, see respectively, Jen-der Lee, n. 7, 2005, and Tonomura, Hitomi. Birth-giving and avoidance taboo: Women's body versus the historiography of ubuya. Japan Review. 2007; 19: 3-45, especially, p. 18 on the use of the white colour and screens in the ubuya. 
movement, and various smells and noises. The more complicated the labour was, the greater bustle, tumult and noise could be expected.

In the aforementioned Tale of Genji, the pregnant woman Aoi goes into labour while suffering from strangling shortness of breath, which the relatives, mediums and diviners interpreted as an interference of a harmful spirit. Loud and intense prayers and acts of exorcism were performed one after another in order to force the spirit to depart, contributing no doubt to the already intense atmosphere of pain, pressure and unrest.

«It was still too early for Aoi to be delivered of her child. Her women were less than fully alert; and then, suddenly, she was seized with labour pains. More priests were put to more strenuous prayers. The malign spirit refused to move. The most eminent of exorcists found this stubbornness extraordinary, and could not think what to do. Then, after renewed efforts at exorcism, more intense than before, it commenced sobbing as if in pain» ${ }^{18}$.

As seen in the childbirth scene in the «Scroll of Hungry Ghosts» discussed earlier, the ritual specialists performing the exorcism would often be sitting outside the birth chamber. However, since these two spaces would only be separated by a thin wall with a sliding door, or a folding screen and a blind, the sounds of mediums being possessed, the Buddhist monks chanting the Lotus Sutra and Fudô incantations, or an exorcism being performed would penetrate the birth chamber affecting the woman in labour and no doubt, intensifying her experience.

The rites of expiating the ghosts would also be accompanied by the burning of incense or special oils, making these smells float freely about the environment. For example, in the Tale of Genji, the robes of the alleged perpetrator of the ghost attack ${ }^{19}$ appeared permeated with the scent of the poppy seeds burnt at exorcisms during Aoi's labour. While presented here as a necessary component of the religious ritual, the burning of poppy seeds in the near vicinity of the birth chamber could also be used as a sedative, providing a soporific effect on the woman in labour, particularly, if she was feeling distressed ${ }^{20}$. In Aoi's case, it meant precisely that; after

18. Seidensticker, n. 4; [1976] 1992, p. 177.

19. Lady Rokujô, the former lover of Genji, was an alleged malign spirit who made the heavily pregnant Aoi, Genji's wife, suffer during labour and eventually die in childbirth. Seidensticker, n. 4; [1976] 1992, p. 177.

20. The use of the poppy seeds as sedatives was well known since ancient times, most likely in ancient Mesopotamia and Egypt. 
a prolonged exorcism (and, needless to say, a difficult labour), the «ghost» stopped bothering her and she felt somewhat better in the midst of this cacophonous environment.

«Thinking that these calmer tones [of Aoi] meant a respite from pain, her mother came with medicine; and even as she drank it down she gave birth to a baby boy. Everyone was delighted, save the spirits that had been transferred to mediums. Chagrined at their failure, they were raising a great stir, and all in all it was a noisy and untidy scene. There was still the afterbirth to worry about. Then, perhaps, of all the prayers, it too was delivered. The grand abbot of Hiei and all the other eminent clerics departed, looking rather pleased with themselves as they mopped their foreheads. Sure that the worse part was past after all the anxious days, the women allowed themselves a rest ${ }^{21}$.

Note that in Aoi's case the medicine, most likely a supplementary drink, prepared by a physician or his aids, was administered after the exorcism, not before or during the rituals. This implies that the efficacy of medical concoctions may have been seen as secondary or complementary to the efficacy of ritual. On the other hand, that Aoi delivers her child immediately after drinking the medicine may imply that the drink could have been a potent concoction that aided a speedy delivery ${ }^{22}$.

Aoi's situation described in the Tale of Genji, although a fictional account, was no doubt based on the contemporary practices. For example, Fujiwara no Michinaga's daughter and the imperial consort Shôshi's labour and childbirth of her son, Prince Atsuhira, was almost a public affair, a precipitously unfolding drama, and a gripping spectacle and a peeping opportunity for some.

To those familiar with the religious life of Heian Japan, the idea of the royal childbirth as a great spectacle may seem odd. Undoubtedly, such worldly pursuits create a tension with the well-known idea that the occurrences of childbirth and death within one's household were the sites of uncleanliness and pollution and thus incurred prolonged periods of ritual abstention from meetings with others and some of the daily activities. Ritual pollution was most certainly assumed and necessary measures were taken to «pay it

21. Seidensticker, n. 4; [1976] 1992, p. 178.

22. Notable in this respect would be the class of drugs based on angelica powder, salvia paste and liquorice powder. Such drugs were used in Sui and Tang Dynasty China «to make foetus slippery», and usually administered throughout the last month of pregnancy. Jen-der Lee, n. 7; 2005, p. 225-227. Also, Tonomura, n. 7 and n. 17. 
off» and cleanse it away ${ }^{23}$, but such considerations did not seem to deter those in attendance at Michinaga's mansion. Shôshi's then lady-in-waiting Murasaki Shikibu recalls in her memoir that

«there must have been forty or more people crammed into the narrow space between the sliding screens to the north and the [childbirth] dais itself. Hardly able to move an inch, they were in trance, quite carried away by it all, and no space could be found for those who had just arrived from home. (...) His Excellency [Michinaga] was shouting orders to all and sundry in such a loud voice that the priests were almost drowned out and could hardly be heard... A group of women (...) squeezed their way in front of the curtains that hung as a divider behind us $^{24}$, with the result that people could barely pass along the narrow corridor at the back (...) and those who did push their way through could hardly tell whom they were jostling» ${ }^{25}$.

Even though the birth chamber was supposed to be nominally separated from the rest of the house by folding screens and blinds, male relatives and ladies-in-waiting were allowed near the white dais on which the parturient woman was supposed to give birth ${ }^{26}$. Far from being serene, it seems as if the place was crawling with people, filled with loud sounds of ritual performances, smoke and for some, even presented a momentous opportunity for an unrelated curiosity.

Describing the scene of Princess Shôshi's labour, Murasaki Shikibu recalls in her diary that «whenever they felt like it, the men would look over the curtains», if only to catch a glimpse of famous court ladies in disarray ${ }^{27}$. These men were primarily the sons of Michinaga, related to the Princess in labour by blood (although Murasaki's diary reports that there were others male courtiers peeking in, from whom such an attitude was far less circumspect). The fictional account in the Tale of Genji also describes

23. Michinaga notes in his diary that certain male courtiers who had been touched upon by such pollution had to be rewarded with stipends for their services. Midô kanpakuki, Kuramoto, n. 9; 2009, vol. 1, p. 364.

24. This means those people, including Murasaki no Shikibu, who were allowed to be present in the birth room in person.

25. Bowring, n.10; 1982, p. 54-55. See also the discussion of pollution and Shôshi's labour in Tonomura, n. 17, 2007; p. 17-19.

26. Bowring provides a useful ground plan of the birth chamber and its surrounding rooms in Fujiwara no Michinaga's mansion. See Bowring, n.10; 1982, p. 202, Ground plan 3, Prince Atsuhira's birth.

27. Bowring, n.10; 1982, p. 55. 
the scene of Aoi's labour and childbirth through the gaze of her husband who takes pleasure by peeping at her through the curtains ${ }^{28}$.

When the woman's labour had entered a crucial stage and it was time to push, this was considered a moment of utmost risk, since it was not always possible to predict the natural course of events. Therefore, preparations were made for the parturient to take the tonsure and assume Buddhist vows in preparation for possible imminent death. In the elite aristocratic household, such as that of Regent Michinaga, expecting the birth of a baby who might become the next emperor, this was undoubtedly a moment of utmost intensity.

«When they started to shave Her Majesty's head and made her take her vows, we were all thrown into utter despair and wondered what on earth was happening; but then she was safely delivered. The afterbirth took some time in coming, so everyone crowded into that huge area that stretched from the main room to the southern gallery and the balustrade, priests and laymen alike, broke once more into chanting and prostrated themselves in prayer» ${ }^{29}$.

Once the baby was safely delivered, this was a cause of joy and celebration as well as the time to amply reward the Buddhist clerics, exorcists and diviners for their performed services.

\section{Midwives and physicians}

As seen from the aforementioned visual, literary and historical sources, in the elite aristocratic households of Heian Japan childbirth was usually supervised by women, such as attendant ladies-in-waiting, elder female relatives and chaperons. They played a crucial role in managing the childbirth and providing the necessary support to the woman in labour: one attendant or midwife would be massaging her back (Jp. koshidaki 腰抱),

28. «Genji drew the curtains back and looked down at his wife. She was heavy with child, and very beautiful... Long, heavy hair, bound at one side, was set off by white robes». Seidensticker, n. 4; [1976] 1992, p. 177.

29. Bowring, n.10; 1982, p. 55. It was not rare for women to die in childbirth; Kishi, another daughter of Michinaga, had a difficult labour and died soon after childbirth during the epidemic of measles in 1025. Hurst, G. Cameron, III. Michinaga's Maladies. A medical report on Fujiwara no Michinaga. Monumenta Nipponica. 1979; 34 (1): 101-112. 
and another, the pregnant belly (Jp. kaihô 懷抱) ${ }^{30}$. The parturient's mother or other older relative would administer the medicine or liaise with those outside the birth room.

However, on a larger scale, the childbirth, particularly in aristocratic households, where the expectation of a male heir often meant increased political prospects, was managed and directed largely by educated and authoritative men, such as family elders or clan heads (often, the aristocratic woman's father, as in the case of Shôshi and Fujiwara no Michinaga) and high-ranking Buddhist clerics. The prominent role of the Buddhist priests, diviners, exorcists and mediums has already been described and acknowledged earlier.

What was the impact of medicine? For a moment, let us turn again to the childbirth scene in the «Scroll of Hungry Ghosts». It gives a prominent space to the figures of female attendants and midwives, performing the rubbing of back and receiving the baby, and a Buddhist monk and a miko medium. There is still the puzzling figure of a male courtier in a ceremonial cap and plain robes, who appears to be walking in or peeking into the birth chamber through the sliding door on the right-hand side of the scroll's fragment. Could he be a physician, or simply a concerned relative?

As seen from the descriptions of aristocratic women's labour in the literary sources and diaries discussed above, it would not be unusual that a male courtier, possibly a husband or a blood relative would peep into the birth chamber. If so, the childbirth scene in the «Scroll of Hungry Ghosts» would seem to imply that the presence of a physician was either an impossibility or not always necessarily a high priority ${ }^{31}$. The court diaries, such as that by Fujiwara no Michinaga, and other court records such as Osan oinori no mokuroku (A List of Prayers for the August Childbirth) and Osan buruiki (The Assorted Accounts of the August Childbirth) ${ }^{32}$, which documented the ritual processions and prayers during royal childbirths between 1126 and 1338 , mention physicians only scarcely.

30. Shinmura, Taku 新村拓. Nihon iryô shakaishi no kenkyû日本医療社会史の研究. (The social history of Japanese medicine, Tokyo: Hôsei Daigaku Shuppankyoku; [1985] 1990, p. 257.

31. The «Scroll of Hungry Ghosts» is by no means the only medieval scroll portraying the childbirth scene. Other examples appear also in the Kitano Tenjin engi emaki and other hand-painted emaki scrolls. Due to space, they cannot be discussed here at length.

32. The English translation of these texts, currently undertaken by the author, will be addressed in a larger study. 
However, this does not imply a total absence of physicians from the scene of childbirths in Heian Japan. Moreover, their activities, education and contribution to the knowledge about pregnancy and childbirth are still seriously understudied and need to be more thoroughly investigated.

Physicians (Jp. kusushi 薬師) were established as a designated category at court during the early eighth century, when Japan's first state codes, the so-called ritsuryô 律令, were promulgated. Since then, they served at the Bureau of Medicine (Jp. Ten'yakuryô 典薬寮), one of the many departments running state affairs at the imperial court. Although the structure of this bureau changed over time, court physicians' duties evolved around supervising the distribution of medicines and care to the members of the imperial family and attending to the medical needs of court aristocracy. The physicians known from the early historical records were usually low-ranking courtiers (often below provisional seventh and no more than proper fifth rank). During the Heian period (794-1185), the members of the Tanba 丹 波 and Wake 和気 families have become the two hereditary clans of court physicians who came to possess rare medical works, technical skills, and their own family traditions for which they were afforded a certain prestige at $\operatorname{court}^{33}$. Their expertise entailed maladies such as the enteric problems and «common» medical concerns ranging from colds to diabetes, treated by a combination of pharmacopaeic prescriptions, acupuncture and moxibustion.

Among the physicians employed at the eighth-century Bureau of Medicine there were individuals whose duties involved specializing in medical care of the female members of the imperial family and court aristocracy. Called nyoi hakase 女医博士 (professor of women physicians), these male doctors were nominally in charge of imperial consorts' and noblewomen's healthcare, and responsible for educating the female physicians (nyoi or joi 女医) subservient to them ${ }^{34}$. Under the eighth-century Ritsuryô codes, the latter belonged to the Department of Internal Medicine (Jp. naiyakushi 内

33. At least one scholarly view described their professional horizons as «relatively narrow and their skills limited to the treatment of general illnesses and conditions». Goble, Andrew Edmund. War and Injury: the emergence of wound medicine in medieval Japan. Monumenta Nipponica. 2005; 60 (3): 297-338, p. 300. Given that Japan's early medical texts, particularly, those related to women's health, are still relatively understudied in the West, this description may require further assessment and contextualization.

34. Nihon kokugo daijiten, vol. 15, p. 524. Japanese early official records, such as the Shoku Nihongi (Continued Annals of Japan), reported that a professor of female physicians was installed at the Bureau of Medicine in the eleventh month of the sixth year of the Yôrô era (722). 
薬司). Such female physicians were mostly selected from the households of slaves in the public service. Usually girls and young women between fifteen and twenty five years of age, they were taught orally by their hakase the skills of obstetrics, external medicine and massage ${ }^{35}$. Such female physicians attended to the needs of royal consorts and aristocratic women at the top of elite ladder and provided assistance during their labour and childbirth for the reason that the male physicians could not always personally examine them ${ }^{36}$.

By the eleventh century, the structure of state agencies, including the Bureau of Medicine, had changed considerably, although the institution of the female physicians and their professors continued to exist. Most of the time, the direct involvement in the process of labour and childbirth was left to the parturient woman's female assistants and midwives, leaving the male medical authorities to deliver their opinion as an educated guess, often without a direct examination of the woman in labour. However, this does not imply that the male medical authority was without support of substantial technical knowledge. Evidence suggests that Heian-period court physicians were aware of the processes of reproduction and childbirth and some theories of conception and gestation developed earlier in China and, possibly, India.

For example, the earliest extant Japanese collection of medical prescriptions, the Ishinpô 醫心方 (Essentials of Medicine), prepared by the court physician and acupuncturist Tanba no Yasuyori 丹波康頼 (912995) had at least four volumes dealing specifically with women's illnesses, pregnancy, childbirth, and other women health-related issues ${ }^{37}$. Tanba's collection relied largely on the Sui and Tang Chinese medical texts ${ }^{38}$; he quoted more than two hundred sources in total, many of which are now

35. Shinmura, Taku 新村拓. Nihon iryôshi 日本医療史. (The history of Japanese medicine). Tokyo: Yoshikawa Kôbunkan; 2006, p. 24-25.

36. Charlotte Furth has already noted that in China male physicians would be mostly prevented from direct access to the woman in labour, except for extreme emergencies; this situation continued at least until the seventeenth century. Furth, Charlotte. Concepts of pregnancy, childbirth, and infancy in Ch'ing Dynasty China. Journal of Asian Studies, Special issue, «Women in Qing Period China - A Symposium». 1987; 46 (1): 7-34, p.18.

37. Katja Triplett's article in this dossier.

38. Ishinpô contains many references to the Chinese medical classics of the Tang period, such as, for example, the aforementioned «Thousand Golden Formulas», the "Small Articles Formulas» (Ch. Hsiao P'in Fang小品方), the Sui Dynasty's "Classic on Obstetrics" (Ch. Ch'an Ching 産経) and many others. Ôta Tenrei 太田典礼. Annotations to volumes 21-24 of Ishinpô. In: Ishinpô: 
presumed lost. Following these authoritative texts, notably, the Chinese medical work known as the «Prescriptions Worth a Thousand Pieces of Gold» (Ch. Ch'ien Chin Fang 千金方, by Sun Ssu-Miao (581-682)) ${ }^{39}$, Tanba no Yasuyori considered women's conditions, listed mostly in volume 21, more difficult to treat than those of a man ${ }^{40}$.

Volume 22 is the only to contain illustrations and possibly the earliest Japanese source that depicted the ten stages of pregnancy ${ }^{41}$. These handdrawn pictures specified the meridians and points in a woman's body that physicians were to avoid treating with acupuncture at different stages of foetal development ${ }^{42}$. Furthermore, this and subsequent volumes of Ishinp $\hat{o}$ provided prescriptions for treating infertility, bleeding, pain in the back and belly and other conditions during pregnancy and childbirth, procedures during breech birth, as well as divination techniques to determine the gender of foetus, and rituals converting female foetuses into male. Volume 23 , for example, contains a group of prescriptions to be used separately or possibly in succession, in the event of slow placenta delivery. They vary from arcane to the most detailed.

«Boil a bow's string in water and administer it as a potion. Another formula [suggests] application of boar's fat in large quantities (...) Drink sesame oil in small quantities. Take a crossbow string and bind it around the back [of the laboring woman]. Burn a menstruation cloth, make into powder and apply in small quantities (...) Hsiao P'in Fang 小品方 (Prescriptions of Small Items) says, combine wheat and azuki beans ${ }^{43}$, make into a broth and

kaisetsu 醫心方: 解説. (Ishinpô: a commentary), Tokyo: Nihon koigaku shiryô sentaa; 1973. See also Jen-der Lee, n. 7; 2005.

39. Hsia, Emil, Veith, Ilza, and Geertsma, Robert. The Essentials of Medicine in ancient China and Japan. Yasuyori Tamba's Ishimpô. 2 vols. Translated with Introduction and Annotation. Leiden: Brill; 1986, Part I, p. 43. On the medical views of women's bodies in early imperial China, see Wilms, Sabine. «Ten times more difficult to treat»: female bodies in medical texts from early imperial China. Nan Nü. 2005; 7 (2): 182-215.

40. Ôta, n. 38; 1973, p. 172. Also, Ôta Tenrei 太田典礼. Ishinpô, shinkyû hen 医心方 · 鍼炎編 (Essentials of Medicine, volume on acupuncture and moxibustion). Nihon koigaku shiryô sentaa, Tokyo: Shuppan kagaku sôgô kenkyûjo; [1975] 1977: 112-113.

41. Ôta suggests that Tanba's pregnancy charts follow the Chinese model outlined earlier in the «Classic on Obstetrics». Ôta, n. 40; 1977, p. 112. See also, Jen-der Lee, n. 7; 2005; and Choo, Jessey J. C. That «Fatty Lump»: Discourses on the Fetus, Fetal Development, and Filial Piety in China Before the Eleventh Century CE. Nan Nü. 2012; 14: 177-221.

42. Ôta, n. 38; 1973, p. 180-185, and Ôta, n. 40; 1977.

43. Mung beans, Phaseolus mungo, L. Hsia et al., n. 39; 1986, Part 1, p. 111. 
administer as potion (...) As in the «Jewel Inside the Well», ingest the seeds of Chinese parasol tree ${ }^{44}$ in large quantities.

Ch'ien Chin Fang 千金方 (Prescriptions Worth a Thousand Pieces of Gold) says, as in the application of broadleaf cattail ${ }^{45}$, administer the [potion made of?] jujube ${ }^{46}$ in large quantities. Another formula: let the man ingest the azuki [concoction?], seven units, and woman fourteenth units.

Chi Yen Fang 集験方 (Collection of Prescriptions with Proven Effects) says, [take] half a unit of the gojitsu 牛膝 plant ${ }^{47}$ and three units of the aoi seeds 葵子48, and pulverize them. [Mix with] seven units of water and boil. Take three units and divide them in three applications» ${ }^{49}$.

One of these or similar prescriptions may have been used to speed up the delivery of the placenta in the examples described earlier in the eleventh-century literary and historical sources. Such were the situations of the fictional Aoi from the Tale of Genji and the historical Princess Shôshi, the daughter of Regent Michinaga.

The knowledge of women's bodily matters and health conditions was largely confined to the hereditary clans of the court physicians, and possibly, the female nyoi physicians who, however, did not read any medical literature as they only received oral instruction. Although such knowledge was not circulated widely in Heian Japan, the aforementioned part of Ishinpô is one of the few rare sources of early medical knowledge related to obstetrics in pre-modern Japan. The next installation on this subject would not occur until the late thirteenth and early fourteenth centuries, when Buddhist clerics interested in medicine compiled medico-religious texts such as Sansei ruishûshô 産生類聚抄 (Notes on Childbirth, ca. 1318) ${ }^{50}$, and the medieval

44. Seeds of Firmiana simplex, Ch. Wútóng, Jp. go 梧. Hsia et al, n. 39; 1986, Part I: 76, fn. 15 identifies this plant as Sterculia platanifolia, L. f

45. Jp. gamaô 蒲黄 Typha latifolia L. Used in Chinese medicine as a haemostatic to stop bleeding, or as a diuretic.

46. Jp. natsume 東, or Chinese date tree. Ziziphus jujuba.

47. Achyranthes bidentata BI. var. japonica Miq., used in Chinese medicine as a haemostatic, against the blood in urine.

48. Ch, K'uei-tzu, seeds of Malva Pulshella, Bern. Hsia et al, n. 39; 1986, Part 1, p. 90. Otherwise, it could be Malva verticillata. Hollyhock.

49. Ishinpô, vol. 23, no. 14. The Nakarai manuscript, Kokuhô: Nakarai-ke bon Ishinpô, plates 23-17a, 23-17b, 23-18a, vol. 5: 2001-2003. Ôta, n. 38; 1973, p. 189. Regarding the dosage of these prescriptions, the medicines as a rule were meant to be taken before the meals, that is on an empty stomach (Hsia et al, n. 39; 1986, Part I, p. 78).

50. This text has been attributed to the Buddhist priest Kenna 剱阿 (1261-1338) of Shômyôji, a temple near Kamakura in eastern Japan, although the theories about this text's provenance 
physician Kajiwara Shôzen 梶原性全 (1265-1337) wrote his works Ton'ishô 頓医抄 (Book of the Simple Physician, 1304) and Man'anpô 万安方 (Myriad Relief Prescriptions, 1327). The latter introduced new prescriptions and medical treatments mostly imported anew from Song China but adopted by Shôzen to the conditions of Japan ${ }^{51}$. These fourteenth-century texts were further works that addressed, although in different ways, the issues of menstruation, infertility, difficult childbirth, prenatal determination of gender, and were known to contain new methods and prescriptions for treating women's conditions ${ }^{52}$.

\section{Co-existing paradigms of knowledge}

In eleventh-century Japan, labour and childbirth, a critical stage of pregnancy, required a presence of many expert figures, specializing in different systems of knowledge. One was undoubtedly a paradigm of ritual and religious doctrine of Buddhism, which specified that during childbirth women were susceptible to attacks by malevolent spirits and ghosts; manifestations of physical distress were often interpreted as the interference by unseen malignant forces. The labouring women's bodies were therefore at once perceived as sites of uncleanliness and pollution, but on the other hand, particularly, in case of the elite aristocratic women giving birth to future imperial heir, the sites of «building the nation ${ }^{53}$ that required special ritual

vary. This manuscript, now preserved at Kanazawa Bunko, the Shômyôji temple archive in Yokohama, was accessed in March 2012 and March 2013; the author is currently working on its full transcription and English translation. Hattori Toshirô 服部敏郎. Nara jidai igakushi no kenkyû 奈良時代医学史の研究. (A study of the history of medicine in the Nara period (710-794)). Tokyo: Yoshikawa Kôbunkan; [1945] 1994a, p. 159-163. Along with the volumes 21-24 of Ishinpô and sections on women's health in Kajiwara Shôzen's Ton'ishô, this text requires further detailed scholarly attention.

51. A more exhaustive discussion of Shôzen's seminal medical writings can be found in Goble, Andrew Edmund. The Confluences of Medicine in Medieval Japan: Buddhist healing, Chinese knowledge, Islamic formulas, and wounds of war. Honolulu: University of Hawai'i Press; 2011.

52. Goble, n. 33; 2005, p. 307-308. He makes an interesting observation that some of the formulas and treatments offered as a part of women's medical care, mostly to do with bleeding and swelling, (although it is hard to say whether such a category of medical knowledge existed in fourteenth-century Japan specifically) were transferred onto the treatments of wounds, including those received in battles thus giving rise to what Goble described as the «wound medicine» and war injuries.

53. This expression is used here metaphorically, without implying the modern idea of nationstate. 
protection. In both cases, the presence and action by the authoritative male figures (fathers, male relatives, Buddhist clerics) was deemed necessary.

The authority of physicians, usually low-ranking courtiers, was no doubt also taken into account, as far as the patient's situation was concerned. Court physicians, normally prevented by decorum from the direct inspection of aristocratic women in labour, unless absolutely necessary, could use an array of pharmacological and, to a certain extent, physiological knowledge regarding the women's bodies and possible complications during labour and childbirth. Their female counterparts, who were trained in midwifery and possessed a wealth of practical experience, usually assisted at childbirth. The role of such medical practitioners, both male and female, may often be unattested in the written sources and urgently requires further scholarly attention. But ultimately, the events such as childbirth (and death) were commanded by the Buddhist clerics and astrologers whose authority at court as ritual specialists and Buddhist officers was seemingly far greater than their medical counterparts ${ }^{54}$.

\section{Acknowledgments}

The author would like to thank the Cluster of Excellence «Asia and Europe in a Global Context», the Karl Jaspers Centre (University of Heidelberg) and the International Research Center for Japanese Studies (Nichibunken, Kyoto) for their generous support of the various stages of this research, and Dr Lori Meeks for organizing the talk at USC. Thanks go also to Dr Matsumoto Ikuyo (Yokohama City University) for sharing her interest and ideas on this topic in 2010, and to Dr Edward Drott (Missouri State University) and Dr. Prof. Katja Triplett (Göttingen) for their invaluable comments on the preliminary drafts of this paper in 2012-13. After this paper was written, I learned about the ongoing research by Dr Yui Suzuki (University of Maryland) who approaches the similar topics and sources from an art historical perspective. Although her paper could not be quoted on this occasion, I thank Dr Suzuki for sharing the unpublished draft of her paper in March 2014.

54. For example, even in the case of Michinaga's final illness, it was the Tendai abbot Ingen, and not his doctor, the physician Wake no Hironari, who made decisions and provisions for the Regent to be moved into the Amida Hall, the ritual space where the flailing Michinaga was to finally pass over. Hurst, n. 29; 1979, p. 107. Although this example is not related to childbirth, in both these scenarios the ritual arrangements in terms of preparation for death would be relatively similar. 